Review began 01/28/2022 Review ended 02/04/2022 Published 02/08/2022

๑) Copyright 2022

Alnaim et al. This is an open access article distributed under the terms of the Creative Commons Attribution License CC-BY 4.0. which permits unrestricted use, distribution, and reproduction in any medium, provided the original author and source are credited.

\section{Conjunctival Pediatric-Type Follicular Lymphoma in a Young Male: A Case Report and Literature Review}

Abdullah F. Alnaim ${ }^{1}$, Abrar Alhawsawi ${ }^{2}$, Abdulaziz AlSomali ${ }^{3}$, Raneem Jannadi $^{1}$, Sana M. Alsolami ${ }^{4}$, Hammam A. Alotaibi 1, 5

1. Ophthalmology, Dhahran Eye Specialist Hospital, Dhahran, SAU 2. Ophthalmology, University of Jeddah, Jeddah, SAU 3. Ophthalmology, King Faisal University, AL Hasa, SAU 4. Anatomical Pathology, Dammam Regional Laboratory and Blood Bank, Dammam, SAU 5. Research Center, Prince Sultan Military Medical City, Riyadh, SAU

Corresponding author: Hammam A. Alotaibi, hammam1200@gmail.com

\section{Abstract}

Pediatric-type follicular lymphoma is a disease that affects the lymph nodes of the head and neck in the adult and pediatric patient groups. Ocular involvement is exceedingly rare, especially in the pediatrics age group; therefore, keeping a high clinical suspicion is warranted.

Here, we report a rare conjunctival pediatric-type follicular lymphoma in a 15-year-old boy presenting with progressive swelling over the medial aspect of the left bulbar conjunctiva for two months. On examination, the mass was firm, mobile, well encapsulated, wide-based, and had a negative transillumination. An excisional biopsy was performed, and histopathological examination and immunohistochemistry studies revealed lymphoid tissue that was positive for CD20, CD79a, BCL6, and CD10; and negative for BCL2 and MUM1. The CD21 and CD23 positivity highlighted the presence of an expanded follicular dendritic cell meshwork. The patient was diagnosed with conjunctival pediatric-type follicular lymphoma and referred to an oncology center for further examination and treatment.

This lymphoma is rare, requiring high clinical suspicion, and thus, reporting the case detail is important and valuable for ophthalmologists and general pediatrics practitioners alike.

Categories: Ophthalmology, Pediatrics, Oncology

Keywords: ocular cancer, conjunctival growth, head and neck cancer, orbital malignancy, pediatric-type follicular lymphoma

\section{Introduction}

Lymphoma is one of the most prevalent adult orbital malignancies, representing $10 \%$ of all orbital tumors, and around $2 \%$ of all nodal and extra-nodal lymphomas [1,2]. Of all childhood systemic lymphomas, no more than $2 \%$ are pediatric-type follicular lymphoma [3]; this type is seen infrequently in young adults. Pediatrictype follicular lymphoma is classified as a novel variant of follicular lymphoma in the World Health Organization (WHO) classification of lymphomas. This disease predominantly affects males and is most commonly located in the head and neck region [3,4]. We describe a rare case of a well-circumscribed epibulbar conjunctival pediatric-type follicular lymphoma in a young male.

\section{Case Presentation}

This report was approved by the appropriate institutional review board (IRB), and the work was carried out in accordance with the code of ethics of the world medical association (Declaration of Helsinki).

A 15-year-old otherwise healthy boy presented to the emergency department in Dhahran Eye Specialist hospital with a two-month history of progressive swelling over the medial canthus of the left eye. On examination, a pink conjunctival mass over the medial aspect of the left eye was seen. The mass was firm, well encapsulated, mobile, wide-based, and had negative transillumination (Figure $1 A$ ). The right eye had a small, firm, and mobile conjunctival mass on its medial aspect (Figure $1 B$ ). Other ocular structures were unremarkable. No palpable lymph nodes were detected during the examination. 


\section{Cureus}
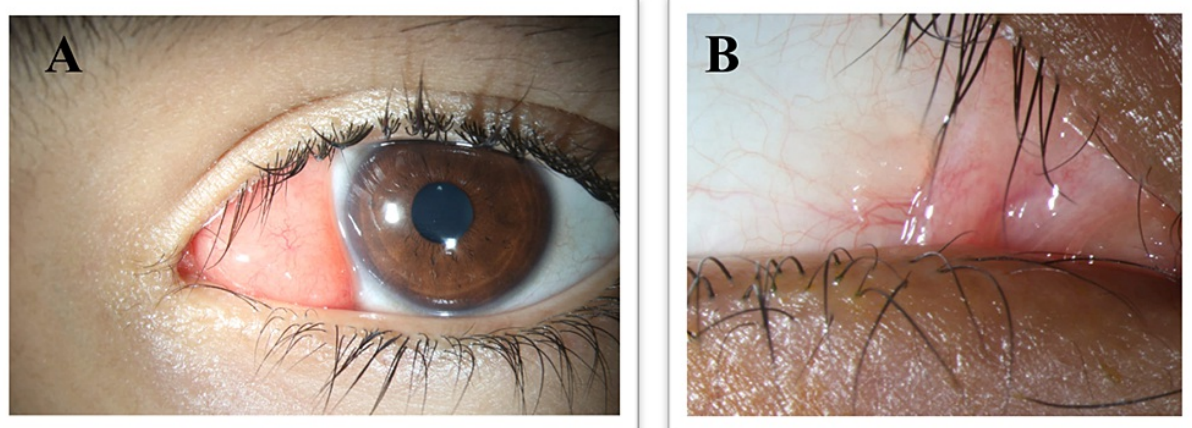

FIGURE 1: Conjunctival mass on the medial aspect of the left $(A)$ and the right $(B)$ eyes of the patient

Anterior segment optical coherence tomography (OCT) was performed and revealed no retinal extension. An excisional biopsy of the lesion in the left eye was performed, and histopathological examination revealed lymphoid tissue with expanded and irregular serpiginous follicles, minimal mantle cell zone, and reduced interfollicular space. The germinal centers were predominantly composed of blastoid cells with numerous mitotic figures and multiple tingible body macrophages, giving the germinal centers a "starry sky" appearance. The blastoid cells were intermediate in size and had nuclear pleomorphism and multiple nucleoli. A few centrocytes and plasma cells were also present within the germinal centers. Reactive follicles were present at the periphery of the specimen (Figure 2).

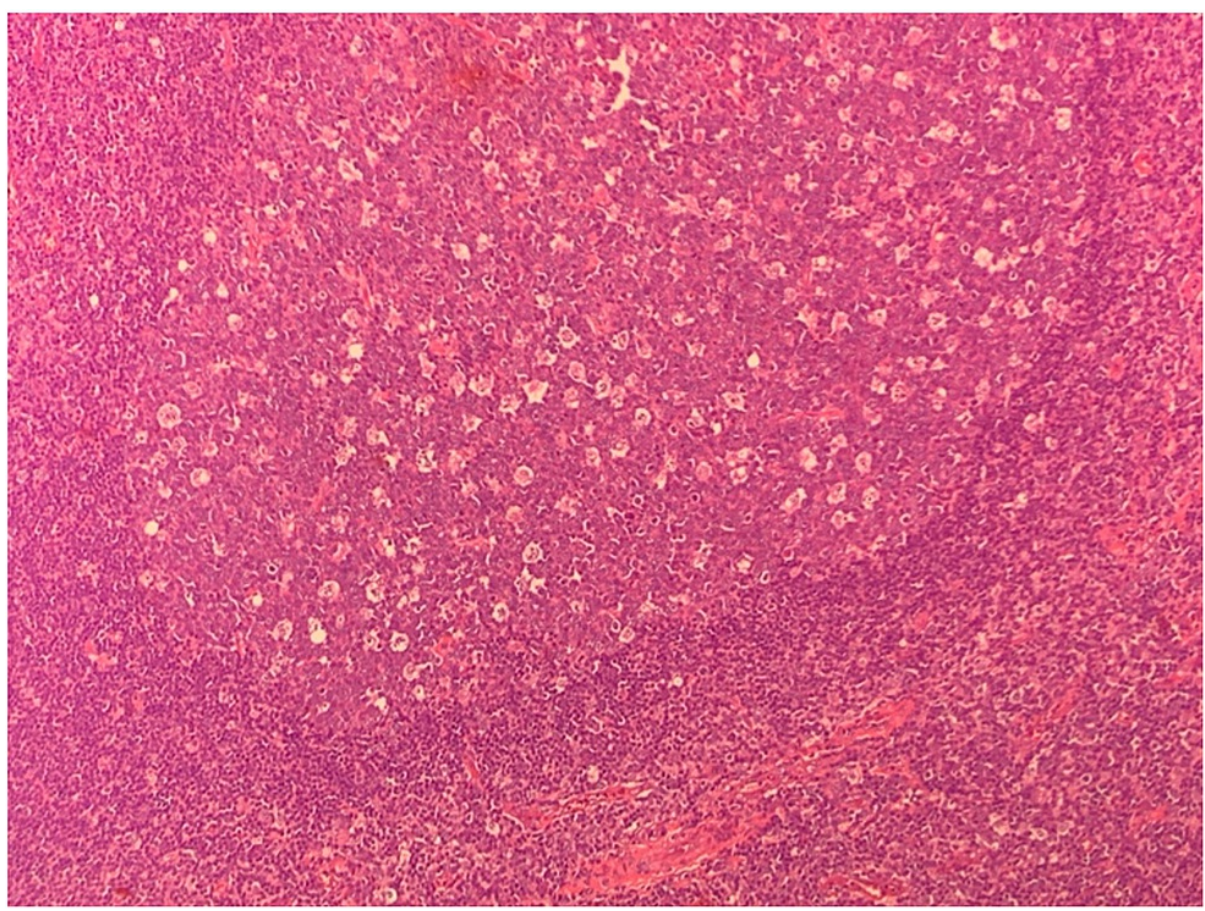

FIGURE 2: Histopathology of biopsy demonstrating a starry sky appearance

Immunohistochemistry (IHC) examination was positive for CD20, CD79a, BCL6, and CD10 (Figure 3), and negative for BCL2 and MUM1 (Figure 4). The interfollicular spaces contained T-cells (CD3+). The CD21 and CD23 positivity highlighted the presence of an expanded follicular dendritic cell meshwork. The Ki-67 proliferation index within the germinal centers was approximately $95 \%$. The patient was diagnosed with conjunctival pediatric-type follicular lymphoma and referred to the oncology center for further examination and treatment. Follow-up at one year post-surgery revealed no recurrence. 


\section{Cureus}
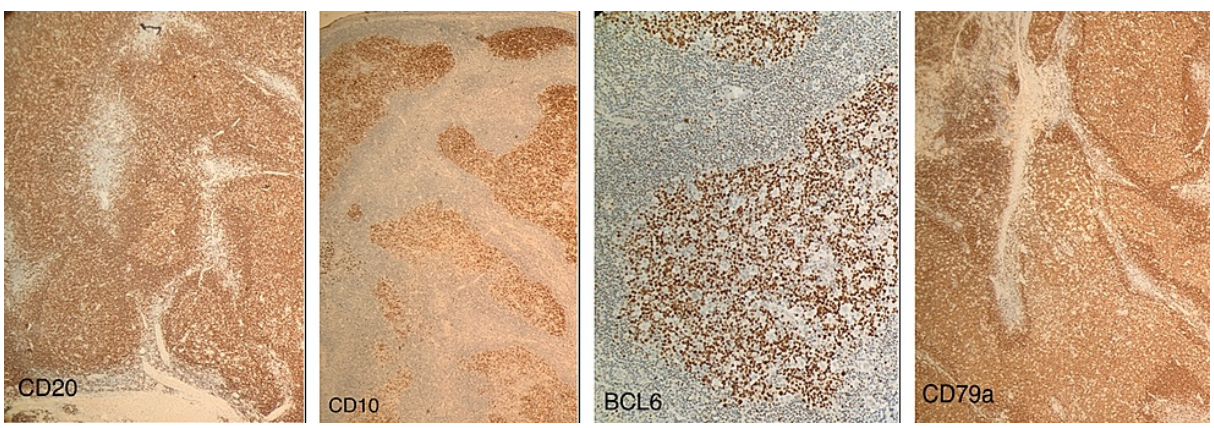

FIGURE 3: Immunohistochemistry of biopsy positive for CD20, CD79a, BCL6, and CD10 indicating lymphoma

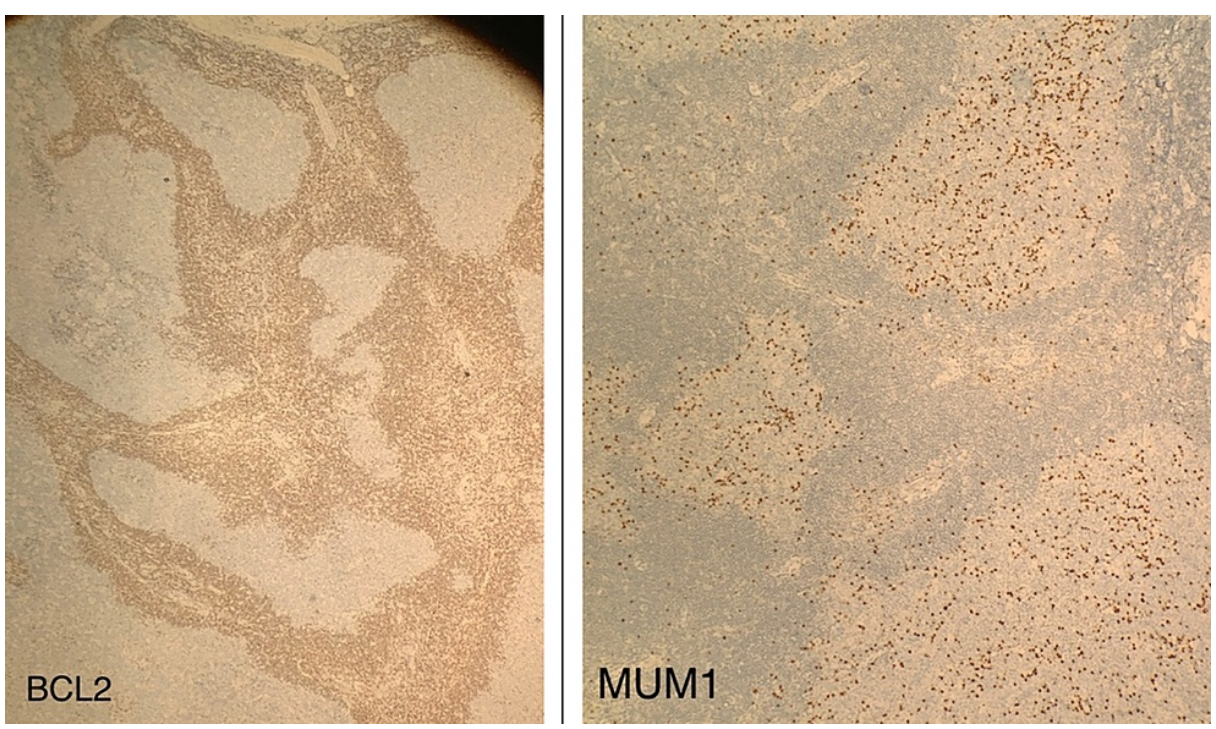

FIGURE 4: Immunohistochemistry of biopsy is negative for BCL2 and MUM1

\section{Discussion}

Conjunctival pediatric-type follicular lymphoma is a rare entity. Only seven cases have been reported in the literature summarized in Table 1 [5-11]. All cases reported were males with ages ranging from six to 21 years. Bilateral involvement was observed in three of the eight cases (two documented previously, the third is presented herein), and the medial bulbar conjunctiva was affected in seven of the eight cases. The duration from onset to presentation ranged from two to six months. 


\section{Cureus}

\begin{tabular}{|c|c|c|c|c|c|c|}
\hline Author(s) & Gender/age & $\begin{array}{l}\text { Affected } \\
\text { eye }\end{array}$ & Gross description & IHC markers & Ki-67 & Treatment and follow-up \\
\hline $\begin{array}{l}\text { Gaffar et } \\
\text { al. } 2010 \text { [5] }\end{array}$ & $\begin{array}{l}\text { Male/ } 6 \\
\text { years }\end{array}$ & Right & $\begin{array}{l}\text { Encapsulated tan-brown } \\
\text { tissue measuring } \\
6.0 \times 3.0 \times 2.5 \mathrm{~mm}^{3}\end{array}$ & $\begin{array}{l}\text { Positive: CD20, BCL6, } \\
\text { and CD10; Negative: } \\
\text { TdT, BCL2, and S-100 }\end{array}$ & $>90 \%$ & $\begin{array}{l}\text { Excisional biopsy with no } \\
\text { recurrence after three years }\end{array}$ \\
\hline $\begin{array}{l}\text { Nazarullah } \\
\text { et al. } 2016 \\
\text { [6] }\end{array}$ & $\begin{array}{l}\text { Male/ } 10 \\
\text { years }\end{array}$ & Bilateral & $\begin{array}{l}\text { Pink mobile nodular } \\
\text { lesions (left: } 6.2 \times 4.3 \mathrm{~mm}^{2} \text {, } \\
\text { right: } 4.8 \times 2.5 \mathrm{~mm}^{2} \text { ) }\end{array}$ & $\begin{array}{l}\text { Positive: CD20, CD10, } \\
\text { and BCL6; Negative: } \\
\text { BCL2 }\end{array}$ & $>90 \%$ & $\begin{array}{l}\text { Excisional biopsy. No } \\
\text { documentation of follow-up duration }\end{array}$ \\
\hline $\begin{array}{l}\text { Perry et al. } \\
2012[7]\end{array}$ & $\begin{array}{l}\text { Male/ } 21 \\
\text { years }\end{array}$ & Left & N/A & $\begin{array}{l}\text { Positive: CD20, CD23, } \\
\text { and CD10; Negative: } \\
\text { BCL2 }\end{array}$ & $>75 \%$ & $\begin{array}{l}\text { ExcISIonal biopsy with no } \\
\text { recurrence after eight months }\end{array}$ \\
\hline $\begin{array}{l}\text { Rodriguez } \\
\text { Torres et } \\
\text { al. } 2016 \text { [8] }\end{array}$ & $\begin{array}{l}\text { Male/ } 11 \\
\text { years }\end{array}$ & Left & $\begin{array}{l}\text { Tan gray mucosal soft } \\
\text { tissue }\left(0.8 \times 0.6 \times 0.3 \mathrm{~cm}^{3}\right)\end{array}$ & $\begin{array}{l}\text { Positive: CD20, CD10; } \\
\text { Negative: BCL2 }\end{array}$ & $>30 \%$ & $\begin{array}{l}\text { Excisional biopsy and radiotherapy } \\
\text { ( } 30 \text { Gy) with no recurrence after two } \\
\text { years }\end{array}$ \\
\hline $\begin{array}{l}\text { Taghipour } \\
\text { Zahir et al. } \\
2013[9]\end{array}$ & $\begin{array}{l}\text { Male/ } 12 \\
\text { years }\end{array}$ & Right & Nodular lesion & $\begin{array}{l}\text { Positive: CD20, BCL2, } \\
\text { and BCL6 }\end{array}$ & NA & $\begin{array}{l}\text { Excisional biopsy with no } \\
\text { recurrence after nine months }\end{array}$ \\
\hline $\begin{array}{l}\text { Wall et al. } \\
2015 \text { [10] }\end{array}$ & $\begin{array}{l}\text { Male/ } 10 \\
\text { years }\end{array}$ & Bilateral & $\begin{array}{l}2 \text { mm oval fleshy well- } \\
\text { circumscribed lesion }\end{array}$ & $\begin{array}{l}\text { Positive: CD20, CD10, } \\
\text { and BCL6; Negative: } \\
\text { BCL2 }\end{array}$ & $>90 \%$ & $\begin{array}{l}\text { Excisional biopsy followed by } \\
\text { rituximab. No recurrence in the left } \\
\text { eye and a smaller lesion in the right } \\
\text { eye after } 15 \text { months }\end{array}$ \\
\hline $\begin{array}{l}\text { AlSemari } \\
\text { et al. } 2020 \\
\text { [11] }\end{array}$ & $\begin{array}{l}\text { Male/ } 18 \\
\text { years }\end{array}$ & Left & $\begin{array}{l}\text { Oval tan-smooth surface } \\
\text { lesion }\left(12 \times 7.5 \mathrm{~mm}^{2}\right)\end{array}$ & $\begin{array}{l}\text { Positive: CD20, CD10, } \\
\text { CD3, and BCL6; } \\
\text { Negative: BCL2 }\end{array}$ & $\sim 75 \%$ & $\begin{array}{l}\text { Excisional biopsy with no } \\
\text { recurrence after two years }\end{array}$ \\
\hline $\begin{array}{l}\text { Case } \\
\text { presented } \\
\text { herein }\end{array}$ & $\begin{array}{l}\text { Male/ } 15 \\
\text { years }\end{array}$ & Left & $\begin{array}{l}\text { Well encapsulated with } \\
\text { wide base, firm, mobile, } \\
\text { and negative } \\
\text { transillumination }\end{array}$ & $\begin{array}{l}\text { Positive: CD20, } \\
\text { CD79a, and BCL6; } \\
\text { Negative: BCL2 and } \\
\text { MUM1 }\end{array}$ & $\sim 95 \%$ & $\begin{array}{l}\text { Excisional biopsy and referral to the } \\
\text { oncology center for further } \\
\text { examination and treatment }\end{array}$ \\
\hline
\end{tabular}

\section{TABLE 1: Summary of the case reports of conjunctival follicular lymphoma in children and young}

men $(n=11)$

$\mathrm{cm}^{3}$ : cubic centimeter, IHC: immunohistochemistry, $\mathrm{mm}^{2}$ : millimeter squared, N/A: not applicable

It is important to consider benign reactive lymphoid hyperplasia in the differential diagnosis. Microscopic examination of reactive lymphoid hyperplasia lesions reveals large interfollicular zones of various sizes and shapes, while in pediatric-type follicular lymphoma, the follicles are similar in configuration and arranged close to each other $[11,12]$.

Histopathological evaluation and IHC studies are essential to diagnose lymphoma. IHC markers were positive for CD20 in all eight cases, for CD10 in seven of eight cases, and for BCL6 in six of eight cases; however, almost all the cases were negative for BCL2, which is predominantly seen in the adult population [5-11]. All patients underwent complete excision, and no recurrences were observed.

\section{Conclusions}

A case of follicular lymphoma in a pediatric patient is documented in this report. Follicular lymphoma of the conjunctiva and sub conjunctiva in the pediatrics age group is rare and could be easily mistaken for a more common entity such as reactive lymphoid hyperplasia. High suspicion of such tumors in children is warranted to provide necessary early treatment. Failing to do so will have a detrimental effect on the morbidity and mortality of the child. Especially given the improved life expectancy when prompt treatment is provided, as evident by this case where treatment was provided at the time of diagnosis leading to preventing recurrence at one year. Immunohistochemistry has an important role to play in the differential diagnosis of the disease, and unique characteristics can be identified, thus aiding in the diagnosis and assessment in selecting the proper treatment regimen for the patient. 


\section{Additional Information \\ Disclosures}

Human subjects: Consent was obtained or waived by all participants in this study. Dahran Eye Specialist Hospital Bioethical Review committee issued approval N/A. Conflicts of interest: In compliance with the ICMJE uniform disclosure form, all authors declare the following: Payment/services info: All authors have declared that no financial support was received from any organization for the submitted work. Financial relationships: All authors have declared that they have no financial relationships at present or within the previous three years with any organizations that might have an interest in the submitted work. Other relationships: All authors have declared that there are no other relationships or activities that could appear to have influenced the submitted work.

\section{References}

1. Briscoe D, Safieh C, Ton Y, Shapiro H, Assia EI, Kidron D: Characteristics of orbital lymphoma: a clinicopathological study of 26 cases. Int Ophthalmol. 2018, 38:271-7. 10.1007/s10792-017-0457-y

2. Eckardt AM, Lemound J, Rana M, Gellrich NC: Orbital lymphoma: diagnostic approach and treatment outcome. World J Surg Oncol. 2013, 11:73. 10.1186/1477-7819-11-73

3. Oschlies I, Salaverria I, Mahn F, et al.: Pediatric follicular lymphoma - a clinico-pathological study of a population-based series of patients treated within the Non-Hodgkin's Lymphoma - Berlin-FrankfurtMunster (NHL-BFM) multicenter trials. Haematologica. 2010, 95:253-9. 10.3324/haematol.2009.013177

4. Campo E, Harris NL, Jaffe ES, Pileri SA, Stein H, Thiele J, Vardiman JW: WHO classification of tumours of haematopoietic and lymphoid tissues. Swerdlow SH (ed): WHO Press, Geneva, Switzerland; 2008. https://hero.epa.gov/hero/index.cfm/reference/details/reference_id/786623.

5. Gaffar M, Thebpatiphat N, Przygodzki R, Jacobs S, Miller MM: Primary follicular lymphoma of the conjunctiva in a 6-year-old child. J AAPOS. 2010, 14:538-40. 10.1016/j.jaapos.2010.08.009

6. Nazarullah A, Dietz L, Wright K, Alkan S, Huang Q: Bilateral conjunctival pediatric follicular lymphoma. J Hematop. 2016, 9:41-5. 10.1007/s12308-015-0260-5

7. Perry LJ, Jakobiec FA, Rubin PA: Conjunctival pediatric follicular lymphoma. Arch Ophthalmol. 2012, 130:941-3. 10.1001/archophthalmol.2011.2529

8. Rodríguez Torres Y, Ramirez AM, Vazquez Botet R: Pediatric conjunctival lymphoma associated with oral carbamazepine use. Am J Ophthalmol Case Rep. 2016, 3:31-3. 10.1016/j.ajoc.2016.04.010

9. Taghipour Zahir S, Miratashi SA, Nazemian M, Zand S: Primary follicular lymphoma of the conjunctiva in a 12 year-old male . Iran J Ped Hematol Oncol. 2013, 3:83-5.

10. Wall PB, Traboulsi EI, Hsi ED, Singh AD: Bilateral conjunctival follicular lymphoma in a child . J AAPOS. 2015, 19:183-5. 10.1016/j.jaapos.2014.10.030

11. AlSemari MA, Maktabi A, AlSamnan MS, Alrajeh MS, Strianese D: Conjunctival pediatric follicular lymphoma: case report and literature review. Ophthalmic Plast Reconstr Surg. 2020, 36:e14-5. 10.1097/IOP.0000000000001500

12. Stacy RC, Jakobiec FA, Schoenfield L, Singh AD: Unifocal and multifocal reactive lymphoid hyperplasia vs follicular lymphoma of the ocular adnexa. Am J Ophthalmol. 2010, 150:412-26. 10.1016/j.ajo.2010.04.007 